\title{
Protein for Sports Persons and Myths about Plant- Based Protein
}

\author{
Dhananjoy Shaw* \\ Indira Gandhi Institute of Physical Education and Sports Sciences, India
}

*Corresponding author: Dhananjoy Shaw, Principal, Indira Gandhi Institute of Physical Education and Sports Sciences, University of Delhi, B-Block, Vikaspuri, New Delhi-110018, India.

Received Date: August 28, 2018

Published Date: August 30, 2018

\section{Protein}

Any of a class of nitrogenous organic compounds which have large molecules composed of one or more long chains of amino acids and are an essential part of all living organisms, especially as structural components of body tissues such as muscle, hair, etc. and as enzymes and antibodies.
a. Protein is raw material for
i. Structure of the body.
ii. Hormones.
iii. Antibodies.
iv. Blood clotting.
v. Enzymes.

b. Not stored in the same way as fat or carbohydrate.

c. 23 amino acids out of which 8 essential amino acid are of great importance.

d. Athletes require more protein than non-athletes.

i. 5 to $15 \%$ of total calories should come from protein.

ii. Protein intake should be tailored to type of training.

1. 1.2 to $1.4 \mathrm{gm} / \mathrm{kg} /$ day recommended for endurance athletes.

2. 1.7 to $1.8 \mathrm{gm} / \mathrm{kg} /$ day recommended for strength athletes.

e. Adequate calorie intake is just as important as adequate protein intake for building muscles.

f. Too much protein intake can be bad.

i. Excess protein calories are stored as fat.

ii. Excess protein intake can lead to dehydration and may contribute to kidney problems (Table 1 \& Table 2).
Table 1: Calculating Protein RDA.

\begin{tabular}{|c|c|c|c|}
\hline Group & $\begin{array}{c}\text { Daily protein } \\
\text { requirements } \\
\text { (g/kg body } \\
\text { weight) }\end{array}$ & $\begin{array}{c}\text { Calculating } \\
\text { your daily } \\
\text { protein } \\
\text { requirement }\end{array}$ & $\begin{array}{c}\text { Example (for } \\
\text { average adult) }\end{array}$ \\
\hline Most adults & $0.8 \mathrm{~g} / \mathrm{kg}$ & $\begin{array}{c}\text { Determine your } \\
\text { body weight. }\end{array}$ & Weight $=110 \mathrm{lb}$ \\
\hline $\begin{array}{c}\text { Recreational } \\
\text { athletes }\end{array}$ & $1.0-1.1 \mathrm{~g} / \mathrm{kg}$ & $\begin{array}{c}\text { Convert pounds } \\
\text { to kilograms: } \mathrm{lb} \\
4-2.21 \mathrm{lb} / \mathrm{kg}\end{array}$ & $\begin{array}{c}110 \mathrm{lb} 4-2.21 \\
\mathrm{lb} / \mathrm{kg}=\mathrm{about} \\
50 \mathrm{~kg}\end{array}$ \\
\hline $\begin{array}{c}\text { Elite athletes in } \\
\text { training }\end{array}$ & $1.2-1.6 \mathrm{~g} / \mathrm{kg}$ & $\begin{array}{c}\text { Multiply by } 0.8 \\
\text { g/kg for average } \\
\text { adult to get } \\
\text { requirement in } \\
\text { grams per day. }\end{array}$ & $\begin{array}{c}50 \mathrm{~kg} \times 0.8 \mathrm{~g} / \mathrm{kg} \\
=40 \mathrm{~g}\end{array}$ \\
\hline $\begin{array}{c}\text { Result: A } 110 \\
\text { lb adult would } \\
\text { need } 40 \text { grams } \\
\text { of protein a day. }\end{array}$ & & & \\
\hline
\end{tabular}

Table 2: Veg Vs Non-veg Protein.

\begin{tabular}{|c|c|c|c|c|c|}
\hline Food & Quantity & Energy & Protein & $\begin{array}{c}\text { Carbo } \\
\text { hydrates }\end{array}$ & Fats \\
\hline Item & & in kcl & in gms & in gms & in gms \\
\hline Meat & $40 \mathrm{gms}$ & 70 & 7 & nil & 5 \\
\hline Milk & $250 \mathrm{ml}$ & 170 & 8 & 12 & 10 \\
\hline Pulses & $30 \mathrm{gms}$ & 100 & 7 & 17 & nil \\
\hline Almonds & $100 \mathrm{gms}$ & 580 & 19.5 & 4.8 & 54.7 \\
\hline Cashew & $100 \mathrm{gms}$ & 580 & 17 & 16.8 & 49.2 \\
\hline
\end{tabular}

\section{Myths about Plant-Based Protein}

You Can't Get Enough Protein from Plant-Based Diets. The idea that plant-based diets lack sufficient protein isn't true. Here are five benefits of eating plant-based proteins

1. Low in saturated fat.

2. Free of the growth hormones and antibiotics found in animal proteins. 
3. Alkaline-forming.

4. Easy to digest.

5. Better for the environment.

\section{Plant-based proteins aren't complete}

When choosing a variety of beans, grains, and vegetables, for example, you don't have to worry about which ones are complete or not.

\section{Animal protein is the only protein that builds muscle}

The best protein comes from whole food, alkaline-forming sources, such as lean, plant-based protein- found in sprouted nuts, seeds, or grains. Not only will you be getting complete proteins, but plant-based proteins are rich in antioxidants which help to reduce the inflammation caused by exercise, helping you to recover faster from your training.

\section{Soybean}

An easy way to include soyabeans in our diet is to add $500 \mathrm{gm}$ of soyabean in $10 \mathrm{~kg}$ of wheat before it is milled. Eat these soya/wheat chapattis instead of regular wheat chapattis for a healthy, nutritious option.

\section{Soybean, mature seeds and raw}

For human consumption, soybeans must be cooked with "wet" heat to destroy the trypsin inhibitors. It is a source of complete protein A complete protein is one that contains significant amounts of all the essential amino acids that must be provided to the human body because of the body's inability to synthesize them. For this reason, soy is a good source of protein (Table 3).

Table 3: Nutritional value per $100 \mathrm{~g}(3.5 \mathrm{oz})$.

\begin{tabular}{|c|c|}
\hline Energy & $\mathbf{1 , 8 6 6} \mathbf{k J}$ (446 kcal) \\
\hline Carbohydrates & $30.16 \mathrm{~g}$ \\
\hline Sugars & $7.33 \mathrm{~g}$ \\
\hline Dietary fibre & $9.3 \mathrm{~g}$ \\
\hline Fat & $19.94 \mathrm{~g}$ \\
\hline Saturated & $2.884 \mathrm{~g}$ \\
\hline Monounsaturated & $4.404 \mathrm{~g}$ \\
\hline Polyunsaturated & $11.255 \mathrm{~g}$ \\
\hline Protein & $36.49 \mathrm{~g}$ \\
\hline
\end{tabular}

\section{Soy Milk}

Soy milk contains about the same proportion of protein as cow's milk: around 3.5\% also $2 \%$ fat, $2.9 \%$ carbohydrate. The dry beans are soaked in water overnight or for a minimum of 3 hours or more depending on the temperature of the water. The rehydrated beans then undergo wet grinding with enough added water to give the desired solids content to the final product. The ratio of water to beans on a weight basis should be about 10:1. The resulting slurry or puree is brought to a boil in order to improve its nutritional value by heat inactivating soybean trypsin inhibitor, improve its flavor and to sterilize the product. Heating at or near the boiling point is continued for a period of time, 15-20 minutes, followed by the removal of an insoluble residue (soy pulp fiber or okara) by filtration. 